\title{
Human Resource Role and Online Strategy
}

\author{
Sari Lestari Zainal Ridho ${ }^{1 *}$, Neneng Miskiyah ${ }^{1}$, Muhammad Anshari $^{2}$, Hadi Jauhari ${ }^{1}$ \\ ${ }^{1}$ Dept. of Business Administration, Politeknik Negeri Sriwijaya, Palembang, Indonesia \\ ${ }^{2}$ School of Business \& Economics, Universiti Brunei Darussalam, Gadong, Brunei Darussalam anshari \\ "Corresponding author. Email: sarilestari@polsri.ac.id
}

\begin{abstract}
The era of industrial revolution 4.0 had force the implementation of technology in all aspect of life, including in the organization operational. While previous studies investigated the effect of human resource role on performance, this study examined the role of human resource presented the organization performance based on the Role Theory perspective. This research analyzed the online service/marketing attributes and predictors of the human resource role, based on online service attributes and organization performance attributes variables. We distributed questionnaire to tourism community in Indonesia in 2019. In this study we used regression to examine the effect of technology application, online marketing, on human resource role within the organization. The result indicated that some online marketing attributes had a positive impact on human resource role within the tourism community performance.
\end{abstract}

Keywords: human resource, technology, online

\section{INTRODUCTION}

Now days, the world is in the era of the forth industrial revolution, marked by the existence of technology, digital information technology, which helps the operational activities of organizations, companies and / or industry. Hence, it becomes a necessity to transform and adapt to the fourth industrial revolution era, as carried out by the Indonesian Ministry of Tourism in carrying out its marketing strategy. The Ministry of Tourism uses online and offline marketing strategies through the activities of the tourism community, that it has formed, in an effort to attract as many visits to Indonesia as possible. This online marketing strategy is carried out by reason of the increasing number of cellular phone users and the number of internet users.

The number of cellular phone users and the number of internet users in Indonesia, based on data from the Central Statistics Agency from the National Socio-Economic Survey, there was an increase in cellular phone users during the 2013-2017 periods, which was originally as much as 50.49 percent in 2013 to 59.59 percent in 2017 . Likewise, the number of households accessing the internet, which originally amounted to $31.75 \%$ in 2013 , became $57.33 \%$ in 2017 . Not only mobile phone users and households accessing the internet, the increase also occurred in internet users, originally amounted to 14.90 percent in 2013 to $32.34 \%$ in 2017 [1].

Given the large number of internet users currently, causing awareness of the Ministry of Tourism to carry out marketing strategies with online marketing/digital marketing through activities by the tourism community formed by the Ministry, which actively promotes
Indonesian tourism through various online media. This online strategy is carried out to capture the opportunities that exist, because it is believed that the rapid progress of the use of information technology can influence organizational performance. The application of technology, as in the promotional activities carried out by the tourism community, in the form of online marketing is expected to increase the role and or performance of the community in its activities in order to increase the number of visits to Indonesia, which is needed to contribute to the economy from tourism industry sector.

Therefore this study aims to examine the effect of online marketing attributes on the role of human resources in the tourism community. According to [2], online marketing has several attributes, namely: transaction or cost; incentive programs; site design; and interactivity, and based on the perspective of role theory [3], performance can be seen from the role of human resources in the form of: role sets, scripts, congruence, expansion, and discrepancy.

Previous research with similar topics has been carried out, including [4], which examines the influence of three resources, namely human resources, information technology, and marketing knowledge on performance. The results of this study [4] indicate that there is a positive performance of the ability of information technology, marketing knowledge, and human resources and the results of the study also stated that the interaction between two or three ways can improve performance. The latest results state that all three abilities are important sources of effort because their abilities significantly improve performance. Other studies have examined the effect of internal marketing on organizational citizenship behaviour and on how online community participation as a moderator is to the relationship between internal marketing and 
organizational citizenship behaviour [5]. The results of the study [5] found that internal marketing has positive results on performance, and online community participation is a moderator in the relationship between internal marketing and organizational citizenship behaviour.

This study is different from previous studies, since there is no prior research that examines the effect of each online marketing attributes on role of human resources respectively, which is the attribute of performance based on the role theory perspective. Previously, [4] treated human resources and information technology as independent variables that influence performance, and in the research of [5], marketing variables are independent variables, and community as variables moderator who influences performance, while in this study, information technology and marketing variables become a unified variable representing the technology application variables in the fourth industrial revolution era in the field of marketing, namely online marketing variables, which will be examined for their effects on the role of human resources, where this variable is the dependent variable and the role of the resource itself is considered to represent performance, because the role of human resources is the performance of individuals who are part of organizational performance. It can be said simply that, this study examined the online service attributes and predictors of the human resource role in organization performance, based on online service attributes and organization performance attributes variables.

The paper is organized as follows: in section 1 we discussed the introduction, and then in section 2 we describe the theory, in section 3 we describe the method used and we discuss the result in section 4 , and conclude with section 5. Now days, the world is in the era of the forth industrial revolution, marked by the existence of technology, digital information technology, which helps the operational activities of organizations, companies and/or industry. Hence, it becomes a necessity to transform and adapt to the fourth industrial revolution era, as carried out by the Indonesian Ministry of Tourism in carrying out its marketing strategy. The Ministry of Tourism uses online and offline marketing strategies through the activities of the tourism community, that it has formed, in an effort to attract as many visits to Indonesia as possible. This online marketing strategy is carried out by reason of the increasing number of cellular phone users and the number of internet users.

The number of cellular phone users and the number of internet users in Indonesia, based on data from the Central Statistics Agency from the National Socio-Economic Survey, there was an increase in cellular phone users during the 2013-2017 periods, which was originally as much as 50.49 percent in 2013 to 59.59 percent in 2017 . Likewise, the number of households accessing the internet, which originally amounted to $31.75 \%$ in 2013 , became $57.33 \%$ in 2017. Not only mobile phone users and households accessing the internet, the increase also occurred in internet users, originally amounted to 14.90 percent in 2013 to $32.34 \%$ in 2017 [1].
Given the large number of internet users currently, causing awareness of the Ministry of Tourism to carry out marketing strategies with online marketing/digital marketing through activities by the tourism community formed by the Ministry, which actively promotes Indonesian tourism through various online media. This online strategy is carried out to capture the opportunities that exist, because it is believed that the rapid progress of the use of information technology can influence organizational performance. The application of technology, as in the promotional activities carried out by the tourism community, in the form of online marketing is expected to increase the role and or performance of the community in its activities in order to increase the number of visits to Indonesia, which is needed to contribute to the economy from tourism industry sector.

Therefore this study aims to examine the effect of online marketing attributes on the role of human resources in the tourism community. According to [2], online marketing has several attributes, namely: transaction or cost; incentive programs; site design; and interactivity, and based on the perspective of role theory [3], performance can be seen from the role of human resources in the form of: role sets, scripts, congruence, expansion, and discrepancy.

Previous research with similar topics has been carried out, including [4], which examines the influence of three resources, namely human resources, information technology, and marketing knowledge on performance. The results of this study [4] indicate that there is a positive performance of the ability of information technology, marketing knowledge, and human resources and the results of the study also stated that the interaction between two or three ways can improve performance. The latest results state that all three abilities are important sources of effort because their abilities significantly improve performance. Other studies have examined the effect of internal marketing on organizational citizenship behaviour and on how online community participation as a moderator is to the relationship between internal marketing and organizational citizenship behaviour [5]. The results of the study [5] found that internal marketing has positive results on performance, and online community participation is a moderator in the relationship between internal marketing and organizational citizenship behaviour.

This study is different from previous studies, since there is no prior research that examines the effect of each online marketing attributes on role of human resources respectively, which is the attribute of performance based on the role theory perspective. Previously, [4] treated human resources and information technology as independent variables that influence performance, and in the research of [5], marketing variables are independent variables, and community as variables moderator who influences performance, while in this study, information technology and marketing variables become a unified variable representing the technology application variables in the fourth industrial revolution era in the field of marketing, namely online marketing variables, which will be examined for their effects on the role of human 
resources, where this variable is the dependent variable and the role of the resource itself is considered to represent performance, because the role of human resources is the performance of individuals who are part of organizational performance. It can be said simply that, this study examined the online service attributes and predictors of the human resource role in organization performance, based on online service attributes and organization performance attributes variables.

The paper is organized as follows: in section 1 we discussed the introduction, and then in section 2 we describe the theory, in section 3 we describe the method used and we discuss the result in section 4 , and conclude with section 5 .

\section{LITERATURE REVIEW}

One of capital or resources of an organization is human. Human is considered as an important resource for organizational competitiveness[6]. Humans are trusted as organizational resources that affect productivity [7]. Human resources are task completion resources and are responsible for the tasks assigned by the organization. The results of the implementation / completion of the tasks given were defined as performance [8]. With regard to Performance, [9], does not mention the existence of classifications in defining performance, while [8], classifies performance in organizations into two, namely individual performance (work results produced by someone) and organizational performance (overall organizational work results ) Therefore, it is not surprising that human resource policies and management are often identified with organizational performance [10]

Individual performance is one example that includes service performance. One of the theorems that examines service performance is role theory, which was developed by [2], according to him, Role Theory is the study of individual behaviour in certain positions, namely about the extent to which it can act appropriately, position or role. These roles include: role sets, scripts, congruence, expansion, and discrepancy. According to [11], the role theory, is able to increase understanding of service interactions in marketing, and explain how role management can be used to evaluate the level of interactivity, thus enabling organizations to identify the need for role development for human resources in interactive service activities and allow organizations to oversee service performance.

The use of technology in the era of the 4th industrial revolution today, is a necessity, as well as in the field of marketing, where marketing activities are influenced by digitalization in the work process, including the use of online marketing as a form of application of technology in providing interactive personal services. Attributes of using product sales/marketing services through online according to [2] consist of four factors, namely transaction/cost; incentive programs; site design; and interactivity [12], examines the relationship between the application of digital technology in the business world and performance, by exploring how digital technology contributes to performance. The results of the study indicate that the application of digital technology in the form of the use of social media has a positive impact on business performance. Similar research conducted by [13][14], the result shows that the digital factor has effect on performance, in these studies [13][14], the aim were to evaluate the impact of online marketing use on the tourism community on performance, as measured by the role of human resources.

Therefore based on the purpose of our studies, the hypothesis is: Online marketing attributes (transaction/cost; incentive programs; site design; and interactivity) have a positive and significant influence on the roles of human resources (Role Set, Role Script, Role Congruence, Role Expansion, and Role Discrepancy).

\section{RESEARCH METHODS}

This study employed regression analysis, with the Three Stage Least Square method, to examine the relationship between online marketing and the role of human resources. Before a regression analysis is performed, a pre-test reliability and validity analysis is performed, and also the classical assumption analysis. This research was conducted on members of the tourism community formed by the Ministry of Tourism. The Indonesian Ministry of Tourism uses online marketing strategy as one of the promotional activities undertaken by the tourism community in order to increase the number of visits to Indonesia.

The population of this study is members of the tourism community in Indonesia in 2019, which currently number 15,000 throughout Indonesia [15], based on the total population using the Slovin formula the sample used is approximately 100 people, from a number of questionnaires distributed by random selection, then obtained 110 respondents who can be used as samples in this study.The questions in the questionnaire are made to measure the variables studied, referring to the theory and or previous research regarding online marketing attributes and attributes on role theory for the role of human resource variables [2][3][13] for online marketing consists of 4 attributes, namely: interactive, incentive programs, site design and cost. The interactive attribute measures how easily human resources communicate with and helps respond to tourist questions.

The incentive program attribute measures the benefit/value more than the program as in the case of providing clear information and/or regarding the explanation of tourism products. Site design attributes, measure how far the design of the site used is attractive and neat, and the cost attribute measures the efficiency of using online marketing, as in reducing costs and time. As for the role of human resources consists of 5 attributes, those attribute namely: role set, role script, role congruence, role expansion, and role discrepancy.

The role set attribute measures the usefulness of online marketing in helping to build teamwork and facilitating human resources in serving tourists. The role script 
attribute measures the use of online marketing in helping human resources improve service quality and provide sustainable services. The role congruence attribute measures the usefulness of online marketing in helping human resources attract tourists and provide information. The role expansion attribute measures the usefulness of online marketing in assisting human resources in gaining new tourists, and helping with many tasks. The role discrepancy attribute measures the usefulness of online marketing in helping human resources increase creativity and innovation.

\section{RESULTS AND DISCUSSION}

The results of the initial data processing (pre-test) indicate that, this study has fulfilled all the requirements in the pretest testing, in the form of reliability, validity, classical assumption, and for the validation process, a Goodness-offit measure used is the coefficient of determination $\left(\mathrm{R}^{2}\right)$ and Mean Square Error (MSE), and from the results of the processed data, a goodness-of-fit measure namely RSquare and MSE produced a good enough value for all the equations in the simultaneous equation model.

Furthermore, based on the order conditions, the simultaneous equation model concluded can be identified, so that the next step is estimating the model with 3SLS. The following are given the simultaneous equations which will be estimated using Three Stage Least Square (3SLS):

$$
\begin{aligned}
& \mathrm{Z}_{1}=c_{10}+c_{11} \mathrm{x}_{1}+c_{12} \mathrm{x}_{2}+c_{13} \mathrm{x}_{3}+c_{14} \mathrm{x}_{4}+e_{1} \\
& \mathrm{z}_{2}=c_{20}+c_{21} \mathrm{x}_{1}+c_{22} \mathrm{x}_{2}+c_{23} \mathrm{x}_{3}+c_{24} \mathrm{x}_{4}+e_{2} \\
& \mathrm{z}_{3}=c_{30}+c_{31} \mathrm{x}_{1}+c_{32} \mathrm{x}_{2}+c_{33} \mathrm{x}_{3}+c_{34} \mathrm{x}_{4}+e_{3} \\
& \mathrm{z}_{4}=c_{40}+c_{41} \mathrm{x}_{1}+c_{42} \mathrm{x}_{2}+c_{43} \mathrm{x}_{3}+c_{44} \mathrm{x}_{4}+e_{4} \\
& \mathrm{Z}_{5}=c_{50}+c_{51} \mathrm{x}_{1}+c_{52} \mathrm{x}_{2}+c_{53} \mathrm{x}_{3}+c_{54} \mathrm{x}_{4}+e_{5}
\end{aligned}
$$

Partially/individually testing of the model coefficients with the $t$ test, a significant effect is given when the P-value value $\alpha$ with $\alpha$ is determined at 5\%. From the results of the output table, this test provides some conclusions. Based on data on Table 1, the results of this study indicate that the site design factor was important predictors in determining the role set; site design attributes have a positive and significant effect on the role set attributes with a significant level of significance $(\alpha)$ of $10 \%$.

The site design factor was important predictors in determining the role set. This explains that online/digital marketing with an attractive and neat design affects the role of human resources in building teamwork and makes it easier to serve tourists, because with a site with an attractive and neat design the presentation of information is easily understood both by members of other organizations and by traveller.

The site design attribute has a coefficient value on the role set of 0.186253 ; this shows that site design has a fairly strong influence when compared to other attributes in influencing role sets in the tourism community. Attractive and neat appearance of the site in order to do promotion or online marketing, it is useful in help human resource in making tourists interested in visiting the site and further interested in visiting the tourist destination that is

\begin{tabular}{|c|c|c|c|}
\hline Equation & Variable & coefficient & $\begin{array}{l}\text { P-value } \\
\text { (Prob.) }\end{array}$ \\
\hline \multirow{6}{*}{$\begin{array}{l}\text { Role Set } \\
\left(z_{1}\right)\end{array}$} & Constant & 2,074828 & $0,0001 * * *$ \\
\hline & $\begin{array}{l}\text { Interactive } \\
\left(\mathrm{x}_{1}\right)\end{array}$ & 0,176249 & 0,1340 \\
\hline & $\begin{array}{l}\text { Incentive } \\
\text { Program } \\
\left(\mathrm{x}_{2}\right) \\
\end{array}$ & 0,127855 & 0,2924 \\
\hline & $\begin{array}{l}\text { Site } \\
\text { Design }\left(\mathrm{x}_{3}\right)\end{array}$ & 0,186253 & \\
\hline & & & $0,0849 *$ \\
\hline & $\operatorname{Cost}\left(\mathrm{x}_{4}\right)$ & $-0,007032$ & 0,9464 \\
\hline
\end{tabular}

promoted. These conditions in line with the opinion of [14], which is in their research they stated that attractive site design provides positive value for service users.

Table 1 Role Set t Test Results

* Significant for a significant level $(\alpha)$ of $10 \%$

** Significant for a significant level $(\alpha)$ of $5 \%$.

$* * * *$ Significant for a significant level $(\alpha)$ of $1 \%$

The interactive, incentive program, and site design factors were important predictors in determining the role script, interactive attributes have a positive and significant effect on the role script attributes with a significant level of significance $(\alpha)$ of $10 \%$, incentive programs, and site design has a positive and significant effect on the role script attribute with a significant level of significance $(\alpha)$ of $1 \%$. This explains that online marketing which facilitates community members in communicating, responds to tourists' problems, provides clear information, helps the community in explaining tourism products, attractive and neat designs influence the role of human resources in improving the quality of service for community members and makes it easier to provide continuous service.

Table 2 Role Script t Test Results

\begin{tabular}{|l|l|l|l|}
\hline Equation & Variable & coefficient & $\begin{array}{l}\text { P-value } \\
\text { (Prob.) }\end{array}$ \\
\hline $\begin{array}{l}\text { Role } \\
\text { Script } \\
\left(\mathrm{z}_{2}\right)\end{array}$ & Constant & 1,091120 & \\
\cline { 2 - 4 } & $\begin{array}{l}\text { Interactive } \\
\left(\mathrm{x}_{1}\right)\end{array}$ & 0,179147 & $0,0126^{* *}$ \\
\cline { 2 - 4 } & $\begin{array}{l}\text { Incentive } \\
\text { Program } \\
\left(\mathrm{x}_{2}\right)\end{array}$ & 0,268329 & $0,0678^{*}$ \\
\cline { 2 - 4 } & $\begin{array}{l}\text { Site } \\
\text { Design } \\
\left(\mathrm{x}_{3}\right)\end{array}$ & 0,263179 & $0,0082^{* * *}$ \\
\cline { 2 - 4 } & Cost $\left(\mathrm{x}_{4}\right)$ & 0,003128 & 0,9714 \\
\hline
\end{tabular}

* Significant for a significant level $(\alpha)$ of $10 \%$.

** Significant for a significant level $(\alpha)$ of $5 \%$.

$* * * *$ Significant for a significant level $(\alpha)$ of $1 \%$. 
Interactive attributes, incentive programs, and site design have successive coefficients for role scripts of 0.179147 , $0.268329,0.263179$; this shows that incentive programs have a dominant influence when compared to other attributes in influencing role scripts in the tourism community. In this online promotion activity, the provision of clear information, including in explaining about tourist attractions, improves the quality of sustainable services done by the human resources. This finding in accordance with the research conducted by [16], that incentives have positive relationship with e-service quality.

Table 3 shows that, the results of this study indicate that the incentive program, and cost factors were important predictors in determining the role congruence, the incentive program attributes had a positive and significant effect on the role congruence attributes significantly for a significant level $(\alpha)$ of $5 \%$, and cost had an influence which is positive and significant towards the role congruence attribute with a significant level of significance $(\alpha)$ of $1 \%$.

Table 3 Role Congruence t Test Results

\begin{tabular}{|l|l|l|l|}
\hline Equation & Variable & coefficient & $\begin{array}{l}\text { P-value } \\
\text { (Prob.) }\end{array}$ \\
\hline $\begin{array}{l}\text { Role } \\
\text { Congruence } \\
\left(\mathrm{z}_{3}\right)\end{array}$ & Constant & 1,731700 & \\
\cline { 2 - 4 } & $\begin{array}{l}\text { Interactiv } \\
\mathrm{e} \\
\left(\mathrm{x}_{1}\right)\end{array}$ & 0,022427 & $0,0000^{* * *}$ \\
\cline { 2 - 4 } & $\begin{array}{l}\text { Incentive } \\
\text { Program } \\
\left(\mathrm{x}_{2}\right)\end{array}$ & 0,198025 & 0,8066 \\
\cline { 2 - 4 } & $\begin{array}{l}\text { Site } \\
\text { Design } \\
\left(\mathrm{x}_{3}\right)\end{array}$ & 0,136958 & $0,0368^{* *}$ \\
\cline { 2 - 4 } & Cost $\left(\mathrm{x}_{4}\right)$ & 0,248349 & $0,0024 * * *$ \\
\hline
\end{tabular}

* Significant for a significant level $(\alpha)$ of $10 \%$.

** Significant for a significant level $(\alpha)$ of $5 \%$

$* * * *$ Significant for a significant level $(\alpha)$ of $1 \%$.

These results explains that online marketing that makes it easy for community members to communicate, respond to tourists' problems, provide clear information, help the community in explaining tourism products, and create efficiency in terms of cost and time affects the role of human resources in attracting tourists and helps in providing provide information.

The incentive program, and cost attributes have coefficients successive to role congruence of 0.198025 , 0.248349; this shows that cost has a dominant influence when compared to other attributes in influencing role congruence in the tourism community. These results explain that in carrying out the role of attracting tourists and providing information to them, it is dominantly influenced by the efficiency in terms of cost and time with the use of online marketing. This finding in accordance with theorem that asserted by [17], regarding the correlation between efficiency and technology, according to Him, technology improves operational efficiency and the quality of customer experience.

Table 4 shows that the results of this study indicate that the incentive program, and site design factors are important predictors in determining the role of expansion, the incentive program attributes have a positive and significant effect on the role expansion attributes significantly for a significant level $(\alpha)$ of $1 \%$, and site design has a positive and significant effect on the role expansion attribute with a significant level of significance $(\alpha)$ of $1 \%$.

These conditions explains that online marketing that makes it easy for community members to provide clear information, helps the community in explaining tourism products, attractive and neat designs affect the role of human resources in obtaining new tourists and makes it easy to do many tasks.

Table 4 Role Expansion t Test Results

\begin{tabular}{|l|l|l|l|}
\hline Equation & Variable & $\begin{array}{l}\text { coefficien } \\
\mathrm{t}\end{array}$ & $\begin{array}{l}\text { P-value } \\
\text { (Prob.) }\end{array}$ \\
\hline $\begin{array}{l}\text { Role } \\
\text { Expansion } \\
\left(\mathrm{z}_{4}\right)\end{array}$ & Constant & 1,498913 & $0,0003 * * *$ \\
\cline { 2 - 4 } & $\begin{array}{l}\text { Interactiv } \\
\mathrm{e} \\
\left(\mathrm{x}_{1}\right)\end{array}$ & 0,004391 & \\
\cline { 2 - 4 } & $\begin{array}{l}\text { Incentive } \\
\text { Program } \\
\left(\mathrm{x}_{2}\right)\end{array}$ & 0,466512 & 0,9623 \\
\cline { 2 - 4 } & $\begin{array}{l}\text { Site } \\
\text { Design } \\
\left(\mathrm{x}_{3}\right)\end{array}$ & 0,144719 & $0,0000^{* * *}$ \\
\cline { 2 - 4 } & Cost $\left(\mathrm{x}_{4}\right)$ & 0,033324 & 0,6868 \\
\hline
\end{tabular}

* Significant for a significant level $(\alpha)$ of $10 \%$. ** Significant for a significant level $(\alpha)$ of $5 \%$. $* * * *$ Significant for a significant level $(\alpha)$ of $1 \%$.

The incentive program, and site design attributes have coefficients successively for role expansion of 0.466512 , 0.144719 ; this shows that the incentive program has a fairly large and dominant influence when compared to other attributes in influencing role expansion in the tourism community in provide service to the customer/tourist electronically (e-service). As we mentioned before the better the incentive attribute, the better quality of service given electronically [15], it will support the role expansion of human resource, since in accordance with the prior research, quality of service motivate the customer to come and visit tourism destination [18]. 
The use of online marketing makes it easy for community members to carry out activities or tasks, besides providing clear information, including explaining tourism products, influences the desire of tourists to search for information on the site, thereby increasing the number of visitors to the site, who are also expected to visit tourism products which is offered.

Table 5 Role Discrepancy t Test Results

\begin{tabular}{|l|l|l|l|}
\hline Equation & Variable & coefficient & $\begin{array}{l}\text { P-value } \\
\text { (Prob.) }\end{array}$ \\
\hline $\begin{array}{l}\text { Role } \\
\text { Discrepancy } \\
\left(\mathrm{z}_{5}\right)\end{array}$ & Constant & 2,045741 & $0,0000^{* * *}$ \\
\cline { 2 - 4 } & $\begin{array}{l}\text { Interactiv } \\
\mathrm{e} \\
\left(\mathrm{x}_{1}\right)\end{array}$ & $-0,119871$ & 0,2120 \\
\cline { 2 - 4 } & $\begin{array}{l}\text { Incentive } \\
\text { Program } \\
\left(\mathrm{x}_{2}\right)\end{array}$ & 0,298321 & $0,0027 * * *$ \\
\cline { 2 - 4 } & $\begin{array}{l}\text { Site } \\
\text { Design } \\
\left(\mathrm{x}_{3}\right)\end{array}$ & 0,098421 & \\
\cline { 2 - 4 } & Cost $\left(\mathrm{x}_{4}\right)$ & 0,240626 & $0,0050^{* * *}$ \\
\hline
\end{tabular}

* Significant for a significant level $(\alpha)$ of $10 \%$.

** Significant for a significant level $(\alpha)$ of $5 \%$

$* * * *$ Significant for a significant level $(\alpha)$ of $1 \%$.

Table 5 shows the results of this study indicate that the incentive program, and cost factors were important predictors in determining the role discrepancy, the incentive program and cost attributes had a positive and significant effect on the role discrepancy attribute with a significant level of significance $(\alpha)$ of $1 \%$. This explains that online marketing which makes it easy for community members to provide clear information, helps the community in explaining tourism products, and creates efficiency in terms of cost and time affect the role of human resources in creativity and improvisation.

The incentive program, and cost attributes have coefficients successive to role expansion of 0.298321 , 0.240626; this shows that the incentive program has a quite large and dominant influence when compared to other attributes in influencing the role discrepancy in the tourism community. The creativity and innovation of community members can be increased in providing information and explaining tourism products in Indonesia due to technological assistance in the form of online marketing.

Thus mathematically, the formulation of the simultaneous equation model formed is described as follows:

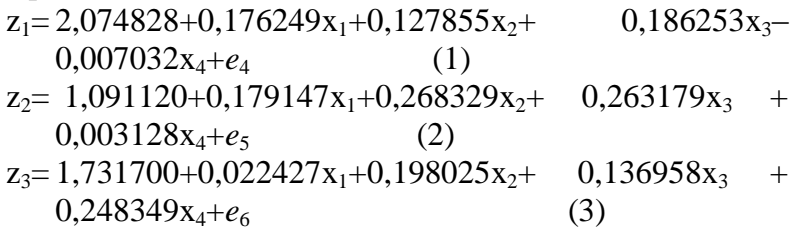

$$
\begin{aligned}
& \mathrm{z}_{4}=1,498913+0,004391 \mathrm{x}_{1}+0,466512 \mathrm{x}_{2}+0,144719 \mathrm{x}_{3}+ \\
& 0,033324 \mathrm{x}_{4}+e_{7} \\
& \mathrm{z}_{5}=2,045741-0,119871 \mathrm{x}_{1}+0,298321 \mathrm{x}_{2}+ \\
& 0,240626 \mathrm{x}_{4}+e_{8} \\
& \text { (4) } \\
& 0,098421 \mathrm{x}_{3}+
\end{aligned}
$$

Overall, based on the this result and discussion, it can be said that in general the result of this study in accordance with the previous findings [4][5][13][14] in term of that the online strategy as implication of technology adoption has impact on performance.

\section{CONCLUSION}

Based on the purpose of this study is to examine the online service/marketing attributes and predictors of the human resource role in organizational performance, in other words to test whether online marketing attributes have a positive and significant effect on the role of human resources. Based on online service attributes and organization performance attributes variables, the results of this study can be concluded that: generally accepting the proposed hypothesis that there is a positive and significant effect of online marketing attributes on the attributes of the role of human resources. This conclusion indicates that the results of this study support previous research which states that there is a positive and significant relationship between online marketing variables and performance.

Nonetheless specifically, the conclusions of the results of this study are different because of the use of different variables and the treatment of different indicators or attributes. The conclusion of this study in detail is that: the site design factor had a positive and significant effect on the role set, the interactive, incentive program, and site design factor had a positive and significant effect on the role script, the incentive program and cost factors had a positive and significant effect on the role congruence, the incentive program and site design had a positive and significant effect on the role of expansion, the incentive program and cost had a positive and significant effect on the role discrepancy.

The implications of this research are it's important for the ministry of tourism to continue to adapt to the use of technology in carrying out its marketing activities in order to increase the number of visits to Indonesia. Furthermore, with the consideration that this study has several limitations, then for the purposes of further research several things can be developed, namely in terms of the variables used, the larger number of samples with more detailed techniques, and different analysis techniques.

\section{ACKNOWLEDGMENTS}

This research was supported by Politeknik Negeri Sriwijaya, Indonesia. The authors thank our colleagues from Politeknik Negeri Sriwijaya who provided insight and expertise that greatly assisted the research. 


\section{REFERENCES}

[1] BPS-Statistic Indonesia, 2018. Telecommunication Statistic in Indonesia 2017. BPS-Statistic Indonesia.

[2] Kim, Eun Young., \& Kim.Youn-Kyung., 2004. Predicting Online Purchase Intentions for Clothing Products. European Journal of Marketing, 38(7): 883-897

[3] Solomon, Michael R., Suprenant, Carol, CZepiel, John A., Gutman, Evelyn G., 1985. A Role Theory Perspective on Dyadic Interactions: The Service Encounter. Journal of marketing, 49: 99111.Broderick, Anna J., 1998. Role Theory, Role Management and Service Performance. Journal of Service Marketing, 12(5): 348-361.

[4] Yang, Yi-Feng, 2008. The Roles of Human Resources, Information Technology, and Marketing Knowledge Capabilities in Performance: An Extension of the ResourceBased Theory Perspective. Social Behavior and Personality, 36(9): 1269-1282.

[5] Chang, Chi-Cheng, Tseng, Kuo-Hung, \& Chen, Che-Wei, 2012. The Moderating Role of Online Community Participation in the Relationship between Internal Marketing and Organizational Citizenship Behavior. Social Behavior and Personality, 40(10): 1725-1738.

[6] Lin, Chuan, Wang, C.Y., Wang, Chen-Yu, \& Jaw, Bih-Shiaw, 2017. The Role of Human Capital Management in Organizational Competitiveness. Social Behavior and Personality, 45(1): 81-92

[7] Hansen, Bjorn Gunnar, \& Greve, Arent, 2015. The Role of Human and Social Capital in Dairy Farming. Rural Society, 24(2):154-176.

[8] Kasmir, 2016. Manajemen Sumber Daya Manusi (Teori dan Praktik). Rajawali Pers. Jakarta.

[9] Fahmi, Irfan, 2017. Manajemen Kepemimpinan (Teori dan Aplikasi). Alfabeta. Bandung.

[10] Kalleberg, Arne L \& Moody, James W., 1994. Human Resource Management and Organizational Performance. The American Behavioral Scientist, 37(7): 948
[11] Broderick, A.1998. Role Theory, Role Management and Service Performance, Journal of Service Marketing, 12(5):348-361

[12] Bouwman, harry, Nikou, Shahrokh, MolinaCastillo, Francisco, J. And de Reuver, Mark, 2017. The Impact of Digitalization on Business Models. Digital, Policy, Regulation, and Governance, 20(2): 7-24

[13] Laksana, Daniel \& Dharmayanti, D., 2018. Pengaruh Digital Marketing terhadap Organizational Performance dengan Intellectual Capital dan Perceived Quality sebagai Variabel Intervening Pada Industri Hotel Bintang Empat di Jawa Timur. Jurnal Manajemen Pemasaran, 12(1): 10-24.

[14] Liesander, Indra \& Dharmayanti, Diah, 2017. Pengaruh Digital Marketing terhadap Organizational Performance dengan Intellectual Capital dan Perceived Quality sebagai Variabel Intervening Pada Industri Hotel Bintang Lima di Jawa Timur. Jurnal Strategi Pemasaran, 4(2): 113.

[15] Purwanto, A. 2019. GenPI Dikenalkan pada Mitra Branding Wonderful Indonesia Retrieved from https://www.genpi.co/berita/8126/genpidikenalkan-pada-mitra-branding-wonderfulindonesia. Date Accessed on 3 September 2019.

[16] Hamid, Noor Raihan Ab, Ahmad, Fauziah, Shah, Saharbudin Naim Tahir, Arshad, Noor Habibah, 2012. E-Service Quality as A Building Block to Long-Term Customer Relationships - A Customer Preference Model. International Journal of Arts \& Sciences; Cumberland, 5(1): 285-302.

[17] Al Fayad, F. S., 2015. Managing Hotel Supply Chain from Inventory to Guest Service: RFID and The Power of Guest Tracking. International Journal of Arts \& Sciences, 08(05): 251-258.

[18] Tian-Cole, Shu, Crompton, John L., \& Wilson, Victor L., 2002. An Empirical Investigation of The Relationship Between Service Quality, Satisfaction and Behavioral Intentions Among Visitors to A Wildlife Refuge. Journal of Leisure Research, 34(1):1-24. 